kunnet kaste yderligere lys over kap. 6 og 7, der berører jødisk forståelse af Torahrullen som helligt, fysisk objekt.

Meget naturligt følger et essay om Josefus og mangfoldigheden i det første århundredes (e.v.t.) former for jødedom. MG fremhæver her problemerne ved at tage Josefus' kortlægning af strømninger inden for tidlig jødedom for gode varer. Beskrivelserne er et ideologisk landkort og ikke det faktiske territorium (34-37, jf. 138f), hvilket ofte glemmes i både nytestamenteforskningen og i studiet af tidlig jødedom, hvor Josefus' skildring af tre grupper ofte identificeres med tidlig jødedom in toto, eventuelt tilsat den 'fjerde filosofi'.

Som yderligere eksempler på vanetænking, MG gør op med, kan nævnes kap. 7 om tekster, skrivere og magt i romersk Judæa, hvor han afmonterer forestillingen om en klasse af skrivere, hvis væsentligste funktion var at undervise i Torahen. Læg dertil kap. 8 om jødisk proselytisme i det første århundrede, hvor han dekonstruerer tanken om, at de Kristustroende skulle have arvet deres missionsiver fra jødedommen. Tidlig jødedom var ikke i dens ikke-Kristustroende former en missionerende religion. I kap. $10 \mathrm{om}$ saddukæernes placering i det første århundredes jødedom gøres der op med det fortærskede billede af saddukæere som velhavende aristokrater af præstebaggrund, der var religiøst konservative og politisk pragmatiske grænsende til det opportunistiske. I kap. 11 om Qumran-sekteristerne, essæerne og Josefus fremhæver MG problemerne med at identificere yahad-teksterne med de græsk-romerske kilders essæerbilleder. Han pointerer, hvordan "it is salutary to recognise that the interpretation of a site through the perspective of literary texts belongs to a tradition of biblical archaeology that archaeologists in other areas of both Jewish and Roman history have been at pains to avoid over the past decades" (142). I kap. 13 slås der et slag for, at både saddukæere og essæere som grupper overlevede templets ødelæggelse i 70 og fortsatte deres eksistens. Sådan kunne man blive ved, men det er tilstrækkeligt til at vise, at man som nytestamentler eller forsker i tidlig jødedom er tvunget til at beskæftige sig med MGs bog, hvis man ikke blot vil fortsætte reproduktionen af forskningshistorisk vanetænkning. Der er altid meget at lære hos MG, og der er mange udfordringer til hans læser.

Anders Klostergaard Petersen

\title{
Thomas Kaufmann
}

"Türckenbüchlein". Zur christlichen Wahrnehmung "türkischer Religion" in Spätmittelalter und Reformation. Forchung zur Kirchen- und Dogmen Geschichte 97. Göttingen: Vandenhoeck \& Ruprecht 2008. 299 s. 26 ill. 1 kort. € 59,90.

I senmiddelalderen og reformationstiden udkom en række skrifter, som sammenfattes under betegnelsen Türckenbüchlein, idet de agtede at bringe oplysninger om religion, kult, sæder, skikke, militære og politiske forhold hos tyrkerne, dvs. i det osmanniske rige. De fleste af skrifterne var skrevet af 
teologer, og i reformationsårhundredet især af lutherske teologer. Forf. vil med nærværende bog se nærmere på det billede, disse skrifter tegner af muslimerne og i særlig grad, hvordan forfatterne beskrev og vurderede deres religion. Forf. afviser at hans hensigt skulle være at bidrage til den aktuelle debat.

Efter nogle metodologiske overvejelser beskæftiger forf. sig først med skrifternes oplysninger om den tyrkiske religion, om enkelte religiøse højtideligheder, skikke, bygninger, om koranen og om personen Muhammed. Dernæst skildres skrifternes anvendelse internt i kristendommen af det tegnede skrækbillede, dvs. hvorledes kristne af begge konfessioner kunne foretage en tyrkisering af modstandere inden for kristendommen. Videre undersøges forholdet i 1500-tallet mellem billedet af tyrken og den europæiske identitet, de eskatologiske perspektiver og den eventuelle sammenhæng mellem tyrkerfaren og den protestantiske reformations udbredelse. Bogen er opbygget på den måde, at forf. først behandler disse, og adskillige andre, emner i en tekstdel på godt 60 sider. Derefter følger godt 30 sider med billeder, som efterfølges af bogens største afsnit, Anmerkungen. Ikke færre end 613, som fylder 128 sider. Nogle af disse noter fylder et par sider. Her citeres længere uddrag af de pågældende skrifter, andre udsagn fra andre samtidige skrifter tilføjes, ligesom der i hvert enkelt tilfælde bringes fyldige oplysninger om relevante, nyere forskningslitteratur og kildeudgivelser. Endelig findes fortegnelser over de behandlede kildeskrifter og forskningslitteraturen samt registre.

De mange skrifter vil bringe "objektive" oplysninger om islam, men bygger ikke på Koranen, men på rejseoplevelser, tilfangetagnes oplysninger og lignende. De vil samtidig forsvare kristendommen og opfordre de kristne til bod og alvorligt kristenliv. Tyrken blev ganske vist opfattet som Guds svøbe på grund af de kristnes slette levned, et tegn på de eskatologiske tiders begyndelse, men samtidig kunne både lutherske og katolske enes om militært at bekæmpe tyrkerne, og dette skulle ske under - den katolske - kejsers ledelse. Trods dette dristede de lutherske fyrster sig til at kræve indrømmelser mht. deres gennemførte reformationer, dersom de skulle deltage militært.

Bogen bringer et væld af oplysninger fra et kildemateriale, som for de flestes vedkommende ellers er svært tilgængelig. Desuden er det en guldgrube af henvisninger til nyere forskningslitteratur.

Martin Schwarz Lausten

\section{Johann Gerhard}

Exercitium pietatis quotidianum quadripartitum (1612). Latin - Tysk. Udg. og komm. af Johann Anselm Steiger. Doctrina et pietatis. Abt. I Johann Gerhard-Archiv 12. Stuttgart-Bad Cannstadt: frommann-holzboog 2008. 519 s. 4 ill. € 498. 